\title{
Counseling Teacher Competence in Planning Work Programs in the Era of Industrial Revolution 4.0 at SMA Negeri Sekayu District
}

\author{
Marliana $^{1 *}$, Edi Harapan ${ }^{2}$, Rohana ${ }^{2}$ \\ ${ }^{I}$ SMAN 1 Sekayu \\ ${ }^{2}$ Universitas PGRI Palembang \\ *Corresponding author. Email: marliana.sekayu@gmail.com
}

\begin{abstract}
This article aimed to determine how the competence of Counseling Guidance teachers in compiling programs in the Industrial Revolution Era 4.0 at SMA Negeri 1, Sekayu sub-district. In the era of the industrial revolution 4.0, everything was required to change, including in the world of education. Teachers and all stakeholders welcome this change by updating the methods, teaching methods and the way they work because if don't participate in these changes would be left behind. The method that researchers used descriptive qualitative by collecting data through interviews, documentation and interviews with research objects. From the data obtained, it showed that the Counseling Guidance teacher at SMA Negeri 1 Sekayu can arrange the program well. The obstacle faced that in preparing the program, it still required supportive suggestions and infrastructure. Even though it has not been maximized, the obstacles have been overcome by fulfilling the infrastructure, although it was not yet maximized.
\end{abstract}

Keywords: Planning Work Program, Industrial Revolution 4.0, Teacher Competence

\section{INTRODUCTION}

The main objective of the implementation of national education is to realize the intelligence of the Indonesian nation with character, faith, and piety to God Almighty and with noble character. To realize these national ideals, educators are needed including guidance and counseling teachers, hereinafter referred to as Counseling Guidance Teachers. In guidance and counseling services, a counselor needs to have competency skills or skills that include mastery of the following concepts: (1) integrated insight into counseling (meaning, purpose, function, principles, principles, and foundations, (2) approaches, strategies, and techniques through various types of services and activities to support counseling services, (3) preparation of counseling service programs, (4) sources and media of counseling services, (5) assessment and evaluation of the results and processes of counseling services, and (6) management of counseling services [1]

Of the four components, one that has to be mastered by the counseling teacher is professional competence. Based on the professional competence of counselors (Regulation of the Counselor Professional Education,

explains that the activities of conducting guidance and counseling are at point $\mathrm{C}$, which contains (1) designing guidance and counseling programs; (2) implementing a comprehensive guidance and counseling program; (3) assessing the process and results of guidance and counseling activities; (4) mastering the concept and praxis of assessment to understand the conditions, needs, and problems of the counselee [2]

One of the items of professional competence that must be mastered by the counseling teacher is being able to design a work program of guidance and counseling. The purpose of guidance and counseling is to maximize the potential of students and help overcome the problems faced. This guidance and counseling service program is also created to help students develop their potential through special assistance regarding personal, social, learning, career, or other unique educational needs [3] The formulation of this guidance and counseling program is also a measure of the performance of the counseling teacher before carrying out service 
activities. The competence of Counseling Guidance Teachers in compiling guidance and counseling service activity programs is a must-have for counseling guidance Teachers. However, there are still many counseling guidance Teachers who experience problems in preparing guidance and counseling programs.

Currently, we have entered the Industrial Revolution 4.0 Era, in era of the Industrial Revolution 4.0, new technology has emerged which has resulted in extraordinary changes in all areas including the education sector. Technology will make teachers more confident and easier to teach their students so that they can turn classrooms into creative, innovative, and fun learning spaces [4] to face the era of the industrial revolution 4.0, education is needed that can form a creative, innovative, and competitive generation. One of these can be achieved by optimizing the use of technology as an educational aid which is hoped to be able to produce outputs that can follow or change the times for the better. Indonesia also needs to improve the quality of graduates according to the world of work and the demands of digital technology [2]. These all-new demands call for various breakthroughs in thinking, drafting concepts, and actions. In other words, a new paradigm is needed in facing new challenges, said the philosopher Khun. According to the philosopher Khun, if these new challenges are faced using the old paradigm, all efforts will fail. The new challenge demands a breakthrough thinking process if what you want is a quality output that can compete with the work of an open world [5].

The era of the industrial revolution 4.0 will have an impact on the role of education, especially the role of educators. If the role of educators is still to convey knowledge, then they will lose their role along with technological developments and changes in learning methods. This condition must be overcome by increasing the competence of educators who support knowledge for exploration and creation through independent learning [3]. One of the aspects that should be of concern for guidance and counseling teachers to be developed in the era of the Industrial Revolution 4.0 is to become a teacher who is up to date, digital-based technology literate, and has soft skills especially in the fields of Technology, Information and Communication (ICT).

From some of the above views, researchers are interested in researching the competence of Consulting guidance teachers in planning work programs in the era of the industrial revolution 4.0 in public high schools, Sekayu sub-district. Based on the results of preliminary observations of researchers in high school regarding the competence of counseling teachers in planning work programs in the era of the industrial revolution 4.0, it is found that the work programs compiled by BK teachers have so far followed the Operational Procedure Guidelines (POP) Counseling Guidance from PPPPTK Penjas and Consulting Guidance. The programs are made for annual work programs and semester work programs.

The purpose of this study was to find out how consulting guidance teachers at Sekayu High School plan work programs. In their journey and carrying out their duties, of course, the consulting guidance teachers also experience obstacles in compiling their work programs and the last is how to know the guidance and counseling teachers in overcoming the obstacles they face.

Based on the symptoms that have been presented, variables are needed to measure how to find out the goals that have been put forward, namely the competence of teachers and work programs that are carried out. Competence is not just the ability to carry out administrative tasks alone. However, competence will involve teachings about humans and their behavior, legally humans in carrying out their actions must be in accordance with the norms or rules that apply in their lives [6]. It is emphasized in Government Regulation Number 23 of 2004, concerning Indonesian Teacher Competence which states that competence is the workability of each individual which includes aspects of knowledge, skills, and work attitudes in accordance with established standards.

\section{REVIEWS OF RELATED CONCEPT. 2.1 Counseling and Guidance Teachers}

According to [7] teachers are people who are given the responsibility as educators in the school environment. In another opinion [8]the teacher is a person who is responsible for assisting students in both physical and spiritual development. Meanwhile, [9] argues that teachers are educators, adults who are responsible for providing guidance or assistance to students in developing their body and soul to reach maturity, being able to stand alone can carry out their duties as the caliph of Allah on earth, as social beings, and independent individuals.

Based on the description above, it can be concluded that the teacher is someone who provides learning to students and has expertise in teaching. Guidance and Counseling is a process of assistance provided by mentors (counselors to individuals (counselees) through face-to-face meetings or a reciprocal relationship between the two so that the counselee has the ability or ability to see and find problems and can solve problems on his own Guidance and Counseling are all efforts to assist students to understand themselves so that they can 
direct themselves and act properly under their mental development. These efforts are carried out systematically and continuously. Furthermore, [10] suggests that counseling guidance is a process of providing counselor assistance through interviews so that students can plan for a better future.

Based on the description above, it can be concluded that the efforts to provide assistance to students in order to understand themselves so that they are able to direct themselves and act properly in accordance with their mental development. This effort is carried out systematically and continuously.

\section{METHODS}

This research uses a descriptive qualitative method as according to Nazir in [11] the descriptive method is a method used to examine the status of a group of people, an object, a set of conditions, a system of thought, or a class of events in the present. Data collection techniques use interview techniques where research is face to face with respondents to get the data or information needed [12], secondly, with observation techniques, namely by observing and recording systematically the symptoms that appear on the object of [13] and documentation, namely by collecting data to obtain written facts, namely in the form of documents, reports, archives, and/or other written materials related to the focus of research [9]

\section{RESULTS AND DISCUSSION}

Etymologically, the term competence comes from the English word "competency" which means skill or ability [14] Meanwhile, according to [15]According to [16] argues that competence is the capacity that is in someone who can make that person able to fulfill what is required by work in an organization so that the organization can achieve the expected results.

\section{The Purpose of Counseling Guidance in Formal Education}

In the guidelines for the implementation of guidance and counseling in the formal education pathway (Depdiknas 2008), it is stated that the objectives of the guidance are so that the counselee can: (1) plan study completion activities, career development, and future life; (2) develop all the potential and strength they have to the maximum; (3) adapt to the educational environment, community environment and work environment; (4) overcoming obstacles and difficulties in studying or adapting to the environment.

Based on these general objectives, the specific objectives of guidance and counseling services are then formulated, namely helping the counselee to be able to: (1) understand and accept themselves and their environment; (2) planning activities to complete studies, career development and life in the future; (3) develop the potential optimally; (4) adapting to the environment; (5) overcoming obstacles or difficulties faced in his life and (6) actualizing himself responsibly.

\section{The Challenges of Counseling Guidance Teachers Facing the Industrial Revolution Era 4.0}

In the 21 st century today, every student/counselee is faced with complex, stressful, paradoxical, and uncertain life situations. In the constellation of life, every student/counselee needs a variety of life competencies to develop effectively, productively, and benefit themselves and their environment. The development of life competencies requires an educational service system in schools that does not only rely on learning services for subjects/fields of study and management but also special services that are more psycho-pedagogic, namely through guidance and counseling [17]

Besides, guidance and counseling help students/counselees in choosing, achieving, and maintaining careers to create a productive and physically and mentally prosperous life [1] According to [6] the digital generation of natives considers computer technology communication devices as an integral part of their lives. An individual born in the digital age.

Currently, students/counselees are faced with unique and varied challenges, which have an impact on their personal, social, learning, and career development. To help students/counselees become a generation that is ready to face these conditions, support from various parties is needed synergistically, including counselors.

\section{Counseling Guidance Teacher Competencies in Developing Work Programs. \\ Guidance Consulting teachers at SMA Negeri 1} Sekayu and SMA Negeri 2 Unggul Sekayuare expected to master the competencies of an educator, including pedagogic competence, social competence, personality competence, and professional competence. In professional competence, several items must be mastered by counseling teachers, one of which is designing a continuous work program of guidance and counseling based on the needs of students in a comprehensive manner.

As it has been explained by the Consulting guidance teacher at SMA 1 Sekayu. The working of counseling teachers begins with the distribution of a questionnaire which aims to determine the needs of students. It can be found out from the results of an interview with the counseling teacher at SMA Negeri 
1 Sekayu Mr. David Wahyu Pambudi, S.Pd on December 9, 2020

\begin{abstract}
"The work program plan for guidance and counseling services at SMA Negeri 1 Sekayu is designed based on the results of a study on the needs of students. After making a needs questionnaire, then the questionnaire is given to students so that it can be filled in according to the actual situation. The questionnaire was then processed by the BK teacher to get answers to what the students needed most. From the results of the questionnaire, then the counseling teacher will start planning a work program for one academic year".
\end{abstract}

In line with the above, the work program at SMA Negeri 2 Sekayu according to the results of the interview on December 11, 2020, with Mrs. Eka Novira, M.Pd, it also begins with a study of the needs of students. From the data previously interviewed, according to the Principal of SMA Negeri 1 Sekayu, Mr. Armansyah, S.Pd., MM regarding the professional competence of counseling teachers in planning their work programs, that BK teachers have met competencies in their fields by designing work programs in their fields, this is known according to the results interview on December 8, 2020.

"The guidance and counseling teachers at SMA Negeri 1 Sekayu already have good professional competence in planning work programs for guidance and counseling services, this is known to the principal based on the collection of drafts of the plans that have been made."

\section{The understanding of the Counseling Teacher regarding the Industrial Revolution 4.0}

Regarding the understanding of Insutri Revolution 4.0, it was stated that the Guidance consulting Teachers understand enough about Industry 4.0 revolutions, at least this is proven by the work of the Counseling Guidance teacher using social media and digital devices, according to the results of interviews with school principals.

"BK teachers at SMA Negeri 1 are deemed sufficient to understand what the era of the Industrial Revolution 4.0 is. It can be seen from the work program plan for guidance and counseling services that have also met the needs of the revolutionary era 4.0, for example, in carrying out guidance and counseling services. BK teachers have online counseling services programs through applications or social media, so students can also consult even though they are not facing to face in person. live "
Likewise, what was expressed by Mr. Hendri, S.Pd., M.Si said that:

"In understanding and applying the Industrial Revolution 4.0, the BK teachers are very good. Counseling teachers have the competence to plan guidance and counseling service work programs in the era of the Industrial Revolution 4.0, and can apply it in the form of online consulting services, providing information services has also used the platforms available on the internet. So that even in conditions of distance learning like this, the counseling teacher can still meet the needs of students ".

Likewise, what was expressed by Mr. Hendri, S.Pd., M.Si said that:

"In understanding and applying the Industrial Revolution 4.0, the BK teachers are very good. Counseling teachers have the competence to plan guidance and counseling service work programs in the era of the Industrial Revolution 4.0, and can apply it in the form of online consulting services, providing information services has also used the platforms available on the internet. So that even in conditions of distance learning like this, the counseling teacher can still meet the needs of students ".

Thus it can be concluded that the counseling guidance teacher has understood his performance and has adjusted to the existing conditions. This situation is in the form of the use of digital technology and social media as the latest media in the use of technology.

Constraints faced and how to overcome them in planning work programs in the industrial revolution era 4.0

In carrying out its performance, the Tutor Guidance teacher is considered to have performed well. The obstacles that have arisen have been resolved properly by updating the knowledge updates about the Industrial Revolution, using the infrastructure that has been provided, and using the existing media groups in consultation. This is as stated by the principal

"The efforts made by Guidance Counseling Teachers in overcoming the existing obstacles are right. The $B K$ teacher uses the existing facilities or uses the facilities and infrastructure owned by the BK teacher himself. To increase knowledge and upgrade knowledge about the 4.0 Industrial Revolution, counseling teachers can take advantage of professional teacher organizations such as MGBK (Guidance and Counseling Teacher Meeting), ABKIN 
(Indonesian Guidance and Counseling Association), PGRI, or IGI"

According to the subject teacher at SMA Negeri 1 Sekayu Ibu Hj. Erni Syuib, S.Pd and homeroom teacher Selvi Yani, S.Pd said that overall the BK teachers have made efforts to overcome the obstacles that exist in the planning of work program services for guidance and counseling activities. . For facilities and financial needs, Guidance and Counseling teachers usually submit funds to the head of the school, to meet the needs of program planning in the era of the Industrial Revolution 4.0.

The same statement was also given by the Counseling Guidance teacher that the obstacles faced so far have been able to be overcome by utilizing existing facilities and those provided by the school. As for those related to facilities that are not yet supported, they are submitted to the school and adjusting the existing financial conditions.

\section{CONCLUSION}

From the results of the above research, it can be concluded that the Bimpingan Teachers at SMA Negeri 1 Sekayu and SMA Negeri 2 Unggul Sekayu have sufficient competence in planning work programs for guidance and counseling services in the era of the Industrial Revolution 4.0. The Counseling Guidance teacher has planned a work program under the procedure, namely carrying out a need assessment at the beginning of the work program planning.

From making assessments to planning work programs, digital technology is used, namely using applications not in the conventional way, and the contents of the programs created also use interactive media. This can be seen in detail from the Service Implementation Plan (RPL) that has been made.

\section{REFERENCES}

[1] Prayitno., \& Eman, A. (2012). Dasar-Dasar Bimbingan dan Konseling di Sekolah. Bandung: Alfabeta.

[2] Afandi., \& Sajidan. (2017). Pendidikan Dalam Era Revolusi Industri 4.0. Jurnal Pembaharuan, Volume II, Nomor 24, Desember 2017, 13-18

[3] Hermanto. (2019). Pendidikan, Investasi SDM, dan Pembangunan. Jakarta: Balai Pustaka

[4] Utomo, S. S. (2019). Guru di Era Revolusi Industri 4.0. Jurnal Manajemen Pendidikan, XIV(3), 2019, 322-335

[5] Tilaar. (2014). Guru dan Masa Depan. Jakarta: Rajawali Press.

[6] Mardiana. (2011). Era Digital dalam Dunia Pendidikan. Jakarta: Prestasi Pelaja

[7] Purwanto, N. (2017). Administrasi dan Supervisi Pendidikan. Jakarta: Rineka Cipta.
[8] Hamalik. (2014). Kepribadian Guru Indonesia. Jakarta: Raja Graffindo Persada

[9] Djamarah, S. B. (2010). Metode dan Statistika Penelitian. Jakarta: Rajawali Pers.

[10] Faudjia, S. (2018). Bimbingan dan Konseling di Sekolah. Jakarta: Rineka Cipta.

[11] Prastowo, A. (2011). Penelitian Kualitatif: Teknik Mendesain Pembelajaran. Jogjakarta: Diva Press

[12] Sugiyono. (2015). Metode Penelitian Pendidikan, Pendekatan Kuantitatif, Kualitatif dan $R \& D$. Bandung: Alfabeta

[13] Arikunto, S. (2010). Prosedur Penelitian Suatu Pendekatan Praktek. Edisi Revisi. Jakarta: Rineka Cipta.

[14] Kurniasih, I. (2017). Kompetensi Pedagogik, Teori dan Praktik Untuk Peningkatan Kinerja dan Kualitas Guru. Jakarta: Kata Pena.

[15] Rusyan. (2016). Manajemen Peningkatan Kinerja Guru. Konsep Strategi dan Implementasi. Bandung: Remaja Rosdakarya.

[16] Mulyasa, E. (2013). Standar Kompetensi dan Sertifikasi Guru. Bandung: Rosdakarya.

[17] Rojih, A. (2019). Tantangan Guru BK Menghadapi Era Revolusi Industri 4.0. Jurnal Psikologi Pendidikan. XI(2), 219-233. 